\title{
Constitutional Law
}

\section{The Supreme Court (Offices) Act 1997: Loss of a constitutional safeguard}

\section{by Professor G Ganz}

The Act which received the Royal Assent on 17 December 1997 has hardly been headline news, though attention has been drawn in The Guardian to its constitutional significance (Hugo Young, The Guardian, 18 December 1997).

The Bill consisted of one clause, which removed the restriction that the Permanent Secretary of the Lord Chancellor's department must be a barrister or solicitor of ten years' standing (Supreme Court Act 1981 ('SCA'), s. 88 and sch. 2), or a non-lawyer with at least five years experience in the Department (added by the Courts and Legal Services Act 1990, s. 71(2) and sch. 10). The new clause also removed the provisions on tenure and the special retirement age of 72 for the post in SCA, s. 92.

The justification for the change is that the restriction limited the availability of candidates for a department which now employs 11,000 staff and has a budget of $£ 2$ billion (4 HC Deb vol. 300, col. 407 6 November 1997 - Second Reading debate). The Lord Chancellor claimed that there was only one official in the department with the requisite experience to be Permanent Secretary who met the statutory criteria, and that in the whole Civil Service only one other candidate had been identified who was eligible (HL Deb vol. 583, col. 933, 25 November 1997 - Second Reading debate).

The present Permanent Secretary (Sir Thomas Legg KCB, QC, who joined the department in 1962 and has been Permanent Secretary since 1989) is due to retire in April 1998 and the Lord Chancellor explained that the Bill had to have passed through the House of Commons before the selection process could begin, free from the statutory restrictions (HL Deb vol. 583, col. 937, 25 November 1997 - Second Reading debate). As this needed to start by the end of 1997, the Bill had to be introduced in the House of Commons, even though the House of Lords would have been more appropriate.

\section{THE BILL'S PROGRESS}

The Bill was passed through all its stages in the Commons in one day in $3 \frac{1}{2}$ hours with the reluctant acquiescence of the Opposition (HL Deb vol. 300, col. 437, 6 November 1997 - Second Reading debate). The Bill was sent to a committee of the Whole House but as the Deputy Speaker refused to accept manuscript amendments the only debate that took place was on a motion that the clause stand part of the Bill. In the House of Lords there was a one-hour debate on Second Reading (HL Deb vol. 583, col. 932946, 6 November 1997 - Second Reading debate) and as there were no amendments the subsequent stages were purely formal (HL Deb vol. 584, col. 12, 9 December, 1997 and col. 503, 16 December 1997). In that short debate, serious reservations were raised by Lord Woolf, the Master of the Rolls, and Lord Ackner, a retired Law Lord (HL Deb vol. 583, col. 937 and 939, 25 November 1997 - Second Reading debate). It was the Lord Chancellor's constitutional position, as the guardian of the independence of the judiciary, that they felt might be deleteriously affected if the Permanent Secretary did not have the appropriate experience and qualifications.

\section{THE KEY ISSUE}

As was made clear in the House of Commons debate by the Opposition, the key issue is the pivotal role played by the Permanent Secretary in judicial appointments made by the Lord Chancellor. The 'soundings' or consultations, which precede such appointments, are carried out by the Judicial Appointments Group in the department whose head is directly responsible to the Permanent Secretary (HC 52 (1995-96) vol. 2, Evidence p. 155, Third Report from the Home Affairs Committee, 'Judicial Appointments Procedures'). These two men almost always conduct the soundings for the High Court Bench by meeting the senior judges one-to-one (Third Report, q. 43-45). The Opposition tried unsuccessfully to meet the government halfway by suggesting that:

'... the Lord Chancellor should have at his right hand somebody with deep and practical experience of the workings of the department, who has experience of close co-ordination with the legal system generally, and the legal profession and the courts in particular' (HL Deb vol. 300, col. 443, 6 November 1997 - Second Reading debate, Sir Nicholas Lyell).

This aim was not met by the Lord Chancellor's assurance that the Legal Adviser to the Lord Chancellor answers directly to the Permanent Secretary, as do other group heads, most of whom are qualified lawyers and have lengthy experience in the department (HL Deb vol. 583, col. 936, 25 November 1997 Second Reading debate).

\section{EVEN THE TEA BOY ..}

At the time of the introduction of the possibility that the Permanent Secretary of the Lord Chancellor's department could be a non-lawyer with at least five years experience in the Department (Courts and Legal Services Act 1990, s. 71(2) and sch. 10), Lord Ackner commented, 'I imagine that includes the tea boy upwards'. (HL Deb Vol. 515, col. 631, February 5 1990).

It is the Permanent Secretary who at present stands at the apex of the pyramid and plays the pivotal role in gathering and co-ordinating information and advice for judicial appointments. If he can no longer be relied on to act as a constitutional safeguard of judicial independence, a more formal separation of powers may become necessary and an independent commission entrusted with the appointment of judges (HL Deb vol. 583, col. 941, 25 November 1997 Second Reading debate, Lord Hooson). This was rejected by the Home Affairs Committee, HC 52 (1995-96) but was Labour Party policy before the General Election in 1997.

\section{Professor G Ganz}




\section{An introduction to digital signatures}

\section{by Edward Cheng}

W

ith its wealth of electronic information, the Global Information Infrastructure (GII) has the potential to improve services, create new markets and increase overall efficiency. Using the GII, doctors can share opinions and information with medical professionals across the country, enhancing the care that they provide. Some government agencies now accept applications and contract bids in electronic form, reducing needless mountains of paperwork (as an example, the application for the US National Science Foundation scholarship is almost completely on-line). Industry even speculates about widespread electronic commerce in which the public will make transactional purchases on-line. However, all of these promising developments will require the electronic equivalent of a signature that performs two primary functions (in addition to confidentiality, requiring cryptographic solutions)

- Authenticating the identity of the message sender. Like conventional signatures, electronic ones must prove identity. For example, doctors in New York receiving advice from specialists in London need to verify that their colleagues (and not some hacker) sent the message.

- Ensuring the integrity of the message. Paper documents are somewhat difficult to alter because of their physical cmbodiment. In contrast, digital information can be changed without evidence of tampering, making integrity verification critical. For example, stockbrokers need to ensure that transaction orders are neither altered not damaged in transit, since $\$ 1,000$ can easily become $\$ 10,000$.

\section{BACKGROUND READING}

For background information on the operation of digital signatures, reader should consult the works of Daniel Greenwood, Wyrough, Bradford Biddle, A Michael Froomkin or any basic cryptography primer.

\section{ESTABLISHING A LEGAL FRAMEWORK}

Fortunately, digital signatures using public-key cryptography techniques can achieve the two requirements above. From a technical standpoint, digital signatures can prevent a person from falsely claiming that they never sent the message or that the message was altered, a quality called non-repudiation (Charles Merrill, 'An Attorney's Roadmap to the Digital Signature Guidelines' Electronic Banking and Law Report, September 1996, p. 13). However, technical non-repudiation does not automatically translate into legal non-repudiation. If a person uses a digital signature to sign an electronic agreement, it is not necessarily legally binding or enforceable. The law must first recognise the validity of digital signatures, and then it must provide a framework defining the relationships among the various parties (signer, recipient, third parties, etc.). A legal framework will allow judicial systems to uniformly and appropriately attribute liability and accountability.

\section{LEGISLATE EXPEDIENTLY BUT CAUTIOUSLY}

Industry and the public will be reluctant to develop electronic commerce under a cloud of legal certainty. Without a proper legal framework, parties will be exposed to unknown and potentially undesirable risks, discouraging their participation. For example, if a hacker forges a person's digital signature, to that extent they are liable (A Michael Froomkin, 'The Essential Role of Trusted Third Parties in Electronic Commerce', Oregon Law Review 49, 1996). Governments should act swiftly to create the policies and laws required by digital signatures. Case law should play a role, but its development is typically inconsistent, expensive and slow, providing little solace to parties wishing to assess their risk and liability. As a minimum, legislators should develop basic principles to direct and channel the judiciary, who will then flesh out the specifics.

However, as expressed by the UK's Department of Trade and Industry:

'These are complex issues and cannot be rushed. Such changes [in law] will help to underpin secure electronic commerce for a long time to come. We cannot afford to get it wrong.' (Ian Taylor, Licensing of Trusted Third Parties for the Provision of Encryption Services, http://www.steptoe.com/ukpub.htm).

Digital signatures are still an emerging technology and have not yet found widespread use. Thus, governments still have time to form task forces, issue draft legislation, hear testimony and carefully deliberate policy. However, ultimately, they should solidify the digital signature law through legislation, reassuring industry and promoting electronic commerce.

\section{RECENT INITIATIVES}

A number of US states, including Utah, California, Florida, Georgia and Massachusetts, have passed or are currently considering digital signature legislation 'to facilitate commerce by means of reliable electronic messages' (The Utah Digital Signature Act, cited by C Bradford Biddle, 'Misplaced Priorities: The Utah Digital Signature Act and Liability Allocation in a Public Key infrastructure', San Diego Law Review 33, November 1966). However in cyberspace these nuances are unacceptable. Policymakers cannot reasonably expect consumers to track their relevant jurisdiction on the Web and then determine the applicable laws. Even if GII users tried jurisdiction in cyberspace is often ambiguous and undefined. Consequently, businesses and their customers will grow frustrated worrying about potential but unknown laws, obligations and liabilities.

\section{CO-ORDINATED EFFORTS}

Whether through the UN, World Trade Organization (WTO) or some other international body, governments should attempt to adopt uniform digital signature laws uniformly, as required by electronic commerce. This organization should review two avenues for co-ordinating digital signature legislation:

(i) endorsing an existing national, US state or model law and 